\title{
Sulfated Fucan Oligosaccharides Elicit Defense Responses in Tobacco and Local and Systemic Resistance Against Tobacco Mosaic Virus
}

\author{
Olivier Klarzynski,, ${ }^{1,2}$ Valérie Descamps, ${ }^{2}$ Bertrand Plesse, ${ }^{1}$ Jean-Claude Yvin, ${ }^{2}$ Bernard Kloareg, ${ }^{2}$ and \\ Bernard Fritig' \\ ${ }^{1}$ Institut de Biologie Moléculaire des Plantes du CNRS, 67084 Strasbourg cedex, France; ${ }^{2}$ UMR 1931 (CNRS and \\ Laboratoires Goëmar), Station Biologique de Roscoff, Place Georges Teissier, 29680 Roscoff, France.
}

Submitted 1 July 2002. Accepted 9 October 2002.

\begin{abstract}
Sulfated fucans are common structural components of the cell walls of marine brown algae. Using a fucan-degrading hydrolase isolated from a marine bacterium, we prepared sulfated fucan oligosaccharides made of mono- and disulfated fucose units alternatively bound by $\alpha-1,4$ and $\alpha-1,3$ glycosidic linkages, respectively. Here, we report on the elicitor activity of such fucan oligosaccharide preparations in tobacco. In suspension cell cultures, oligofucans at the dose of $200 \mu \mathrm{g} \mathrm{ml}^{-1}$ rapidly induced a marked alkalinization of the extracellular medium and the release of hydrogen peroxide. This was followed within a few hours by a strong stimulation of phenylalanine ammonia-lyase and lipoxygenase activities. Tobacco leaves treated with oligofucans locally accumulated salicylic acid (SA) and the phytoalexin scopoletin and expressed several pathogenesis-related (PR) proteins, but they displayed no symptoms of cell death. Fucan oligosaccharides also induced the systemic accumulation of SA and the acidic PR protein PR-1, two markers of systemic acquired resistance (SAR). Consistently, fucan oligosaccharides strongly stimulated both local and systemic resistance to tobacco mosaic virus (TMV). The use of transgenic plants unable to accumulate $\mathrm{SA}$ indicated that, as in the SAR primed by TMV, SA is required for the establishment of oligofucan-induced resistance.
\end{abstract}

Additional keywords: disease resistance, elicitors, laminarin, oligogalacturonides.

In the course of evolution, plants have developed a complex array of recognition, attack, and defense reactions to protect themselves against potential microbial pathogens (Cohn et al. 2001; Somssich and Hahlbrock 1998). Within minutes, pathogen recognition by the host triggers a variety of early defense responses, such as modification of the ion fluxes across the plasma membrane, phosphorylation and dephosphorylation of signaling proteins, and production of reactive oxygen species (Grant and Mansfield 1999; Nürnberger and Scheel 2001). Within hours, these events are followed by the induction of a broad spectrum of defense reactions that confer local resistance against microbes. These include: i) cell wall reinforcement through lignin synthesis and cross-linking of macromolecular components; ii) production of signaling secondary metabolites from the phenylpropanoid and octadecanoid pathways, such as

Corresponding author: B. Kloareg; Telephone: +33 (0)2 982923 30; Fax: +33 (0)2 982923 24; E-mail: kloareg@ sb-roscoff.fr. salicylic acid (SA) and jasmonates, respectively; and iii) accumulation of components with antimicrobial activities such as phytoalexins and pathogenesis-related (PR) proteins (Kombrink and Somssich 1995). In many incompatible hostpathogen interactions, these defense responses are accompanied by a hypersensitive response (HR), i.e., programmed cell death at the sites of microbial attack. This reaction is thought to benefit the plant as a whole by helping to contain microbes at the attack sites.

Microbe recognition can also result in an increased resistance in the uninfected parts of the plant, a phenomenon known as systemic acquired resistance (SAR) and which confers a long-lasting resistance to subsequent attacks by a broad spectrum of pathogens (Ryals et al. 1996; Sticher et al. 1997). SAR was shown to be inducible in resistant plants challenged with avirulent pathogens, such as $\mathrm{N}$-gene-containing tobacco cultivars infected by tobacco mosaic virus (Ross 1961; Malamy et al. 1990). SAR induction is characterized by the systemic accumulation of some PR proteins, such as the acidic PR-1 in tobacco, and by accumulation of salicylic acid (Malamy et al. 1990). Several lines of evidence suggest that SA is involved in the mechanism of SAR expression. Exogenous application of SA triggers the accumulation of PR proteins as well as the induction of SAR (Ryals et al. 1996; Sticher et al. 1997). In contrast, transgenic plants expressing a bacterial salicylate hydroxylase gene $(\mathrm{NahG})$, which are hence unable to accumulate SA, fail to develop SAR (Delaney et al. 1994; Gaffney et al. 1993). However, even though SA is involved with the establishment of SAR, salicylic acid is probably not the systemically transported SAR signal (Ryals et al. 1996; Sticher et al. 1997). The HR is often associated with the establishment of SAR, and thus, it is commonly thought that HR is a prerequisite for SAR induction (Ryals et al. 1996; Sticher et al. 1997).

Surface components released from the microbe or the host play an important role as signaling molecules involved in the perception of pathogen attacks by plants (Boller 1995; Ebel and Mithöfer 1998; Nürnberger 1999). Many of such exogenous or endogenous elicitors were shown to be cell wall poly- or oligosaccharides, including the microbial $\beta$-glucans and chitin-derived oligomers as well as the plant pectin fragments oligogalacturonides (Côté et al. 1998; Ebel 1998; Ebel and Mithöfer 1998). Since oligosaccharide elicitors were shown to induce at least some of the defense responses described above, these molecules were proposed as new tools for disease control in plants (Albersheim and Darvill 1985; Lyon et al. 1996), and transient resistance can, indeed, be conferred by oligosaccharide application (Reglinski et al. 1994; Benhamou and Nicole 1999). 
Marine macroalgae contain a variety of unique polysaccharides (Kloareg and Quatrano 1988), and some of these were shown to be potential sources of oligosaccharide elicitors for land plants (Klarzynski et al. 2000; Kobayashi et al. 1993; Mercier et al. 2001; Patier et al. 1993, 1995). Here, we report on the elicitor activity of fucan oligosaccharides prepared by the enzyme hydrolysis of a sulfated fucan from a brown alga (Phaeophyta). In tobacco suspended cells, these fucan oligosaccharides induced both early defense responses, such as extracellular medium alkalinization and release of hydrogen peroxide, and late defense reactions, namely induction of phenylalanine ammonia lyase (PAL) and lipoxygenase (LOX),
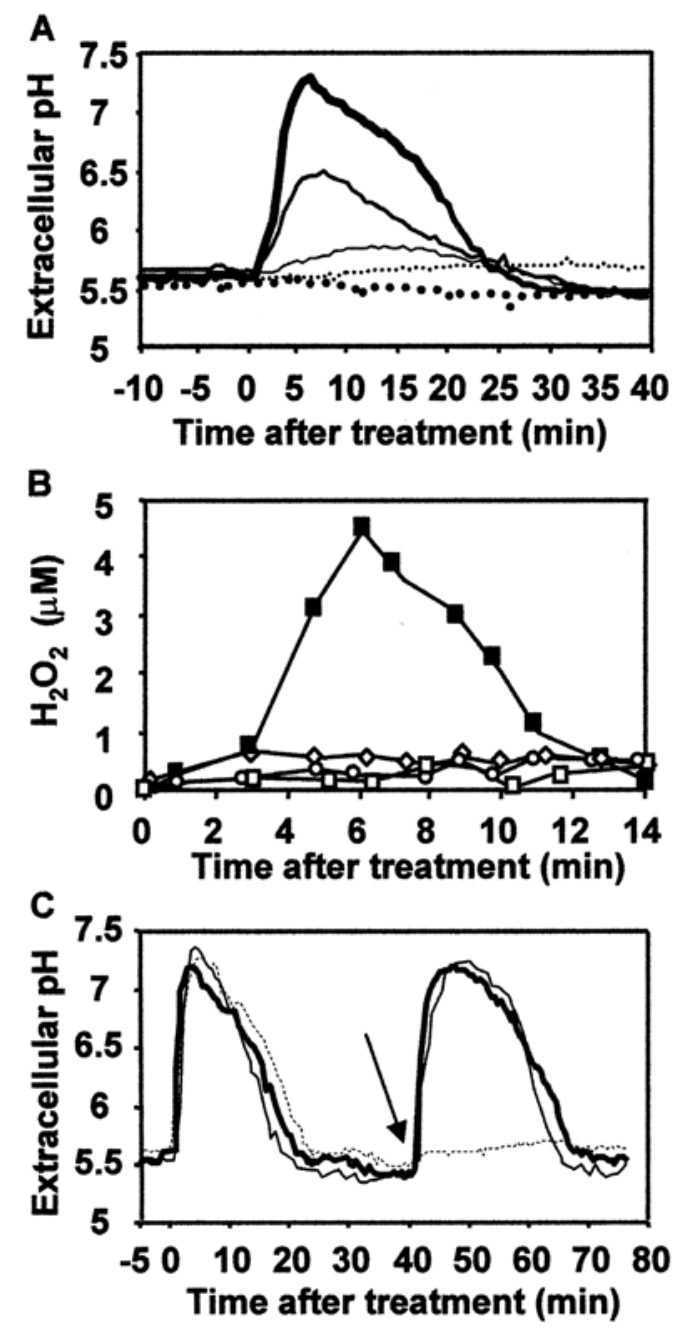

Fig. 1. Alkalinization of the culture medium of tobacco suspension cells and induction of an oxidative burst in response to elicitation with fucan oligosaccharides. A, Alkalinization responses in tobacco suspension cells treated with various doses of fucan oligosaccharides. At time 0 , tobacco cells were treated with $200 \mu \mathrm{g} \mathrm{ml}^{-1}$ (bold line), $20 \mu \mathrm{g} \mathrm{ml}^{-1}$ (medium line), or $1 \mu \mathrm{g} \mathrm{ml}^{-1}$ (light line) of oligofucans. Controls consisted of cells treated with the same volume of water (dotted light line). Tobacco cells were also pretreated for $10 \mathrm{~min}$ with $10 \mu \mathrm{M}$ staurosporine and then treated at time 0 with $200 \mu \mathrm{g}$ of oligofucans $\mathrm{ml}^{-1}$ (dotted bold line). B, Oligofucans-induced oxidative burst in tobacco suspension cells. Tobacco cells were treated at time 0 with $200 \mu \mathrm{g}$ oligofucans $\mathrm{ml}^{-1}$ (black square) or with water (open square), pretreated for 10 minutes with $10 \mu \mathrm{M}$ diphenyleneiodonium and treated at time 0 with $200 \mu \mathrm{g}$ of oligofucans $\mathrm{ml}^{-1}$ (open diamond) or pretreated with $10 \mu \mathrm{M}$ staurosporine and treated at time 0 with $200 \mu \mathrm{g}$ of oligofucans $\mathrm{ml}^{-1}$ (open circle). C, Refractory state analysis between oligofucans and oligogalacturonides or laminarin. After a first treatment with $200 \mu \mathrm{g}$ of oligofucans $\mathrm{ml}^{-1}$ at time $0,200 \mu \mathrm{g}$ of oligofucans $\mathrm{ml}^{-1}$ (dotted line) or $200 \mu \mathrm{g}$ of oligogalacturonides $\mathrm{ml}^{-1}$ (light line) or $200 \mu \mathrm{g}$ of laminarin $\mathrm{ml}^{-1}$ (bold line) were added at the time indicated by an arrow. Data are representative of four replicates. two key enzymes of the phenylpropanoid and octadecanoid pathways, respectively. In tobacco leaves, fucan oligosaccharides locally induced the synthesis of the phytoalexin scopoletin, the accumulation of SA, and of several families of PR proteins. Moreover, tobacco plants treated with oligofucans systemically accumulated SA and acidic PR-1, and they developed SAR against TMV, showing that SAR can be induced by oligosaccharide elicitors. Since fucan oligosaccharides did not induce a HR in tobacco, these results also indicate that HR is not a prerequisite to the development of SAR.

\section{RESULTS}

Oligofucans trigger early defense responses in tobacco cell suspensions.

Treatment of tobacco cell suspension cultures with sulfated oligofucans prepared by the enzymatic hydrolysis of the fucan from the fucoid alga Pelvetia canaliculata induced a transient alkalinization of the incubation medium, starting as early as 30 $\mathrm{s}$ after the addition of the oligosaccharides (Fig. 1A). The maximum $\mathrm{pH}$ shift was observed within $5 \mathrm{~min}$ and was followed by reacidification of the culture medium back to its initial $\mathrm{pH}$ value $25 \mathrm{~min}$ after the addition of oligofucans. The threshold concentration inducing a significant $\mathrm{pH}$ shift was 1 $\mu \mathrm{g} \mathrm{m} \mathrm{m}^{-1}$ (400 $\left.\mathrm{nM}\right)$ and the maximal $\mathrm{pH}$ shift, $1.8 \mathrm{pH}$ units, was reached with $200 \mu \mathrm{g} \mathrm{ml}^{-1}(80 \mu \mathrm{M})$ of oligosaccharides.

A significant release of $\mathrm{H}_{2} \mathrm{O}_{2}$ (up to $5 \mu \mathrm{M}$ ) was also induced by incubation in the presence of $200 \mu \mathrm{g} \mathrm{ml}^{-1}$ of oligofucans, starting approximately $3 \mathrm{~min}$ after the addition of oligosaccharides (Fig. 1B). The burst of activated oxygen species lasted for several minutes, and no further $\mathrm{H}_{2} \mathrm{O}_{2}$ release was observed during the next 3 -h period (data not shown). Preincubation with diphenyleneiodonium (DPI), an inhibitor of macrophage NADPH oxidase (O'Donnell et al. 1993), completely abolished the oxidative burst (Fig. 1B). Similarly, both the oxidative and
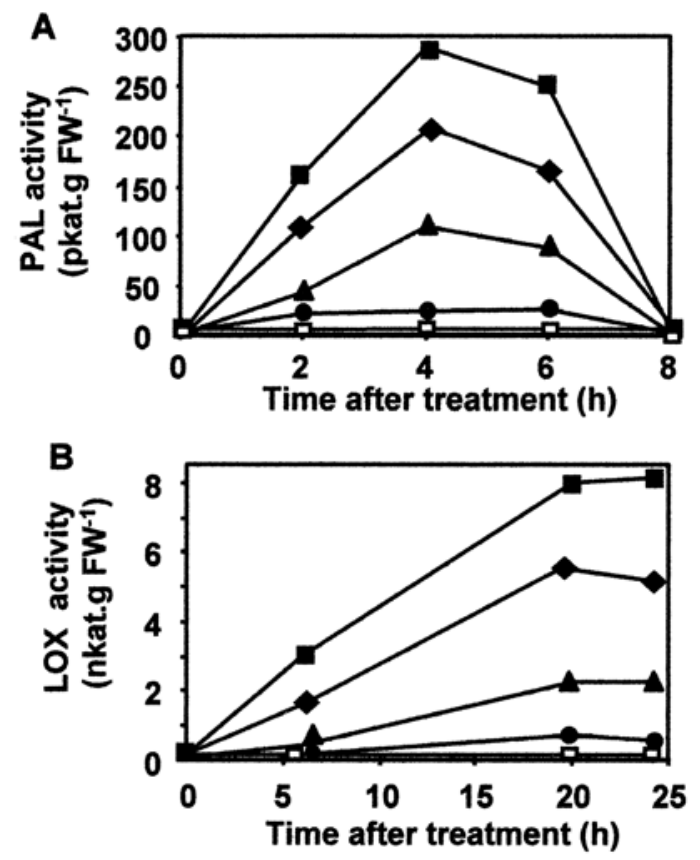

Fig. 2. Induction of phenylalanine ammonia-lyase (PAL) and lipoxygenase (LOX) activities by fucan oligosaccharides in tobacco suspended cells. Time course curves of $\mathbf{A}$, PAL and B, LOX activities in Nicotiana tabacum cv. Bright Yellow cells treated with oligofucans at $200 \mu \mathrm{g} \mathrm{ml}$ (black square), $100 \mu \mathrm{g} \mathrm{ml}^{-1}$ (black diamond), $50 \mu \mathrm{g} \mathrm{ml}^{-1}$ (black triangle), or $1 \mu \mathrm{g} \mathrm{ml}^{-1}$ (black circle) or water (open square). Data are representative of five replicates. 
the alkalinization responses were completely inhibited by pretreatment with staurosporine, an inhibitor of protein phosphorylation (Fig. 1A and B).

Addition of sulfated oligofucans at the end of the $\mathrm{pH}$ shift induced by a first treatment with this molecule did not trigger a second alkalinization response. After a first treatment with fucan oligosaccharides, however, tobacco cells remained reactive to either oligogalacturonides or laminarin (Fig. 1C), two potent elicitors in tobacco (Klarzynski et al. 2000).

\section{Oligofucans both locally and systemically induce a broad range of late defense responses in tobacco.}

A strong induction of PAL was observed following treatment of tobacco cell suspensions with sulfated oligofucans, with the maximum of activity at $4 \mathrm{~h}$ after the addition of the oligosaccharides (Fig. 2A). LOX activity was also stimulated within 4 $\mathrm{h}$ of treatment, with the maximal induction reached between 10 and $20 \mathrm{~h}$ (Fig. 2B). These two responses were dependent on the concentration of oligofucans (Fig. 2A and B). They saturated at about $200 \mu \mathrm{g} \mathrm{ml} \mathrm{m}^{-1}$ oligofucans, as no further increases were recorded for higher elicitor doses (data not shown).

The relevance of oligofucans as elicitors of defense responses in planta was examined by monitoring the accumulation in tobacco plants of several PR proteins belonging to four different PR protein families (Fritig et al. 1998). Compared with leaves infiltrated with water only and as assayed at $48 \mathrm{~h}$ after infiltration (Fig. 3A), the extracts from tobacco leaves treated with $200 \mu \mathrm{g} \mathrm{ml}^{-1}$ oligofucans showed a marked local accumulation of the four PR classes under investigation, namely PR1 (antimicrobial), PR2 (glucanases), PR3 (chitinases), and PR5 (thaumatin-like proteins). In these experiments, the levels of PR protein upregulation in the leaves treated with oligofucans were slightly above those obtained with two other elictor-active oligosaccharides, laminarin and oligogalacturonides (Klarzynski et al. 2000). These extracts also exhibited a strong accumulation of the phytoalexin scopoletin, starting at $48 \mathrm{~h}$ and lasting for several days (Fig. 3B).

Tobacco leaves were then assayed for the local and systemic production of two markers of SAR in plants, SA, and the acidic PR-1 protein (Ryals et al. 1996; Sticher et al. 1997; Ward et al. 1991). In contrast to control tobacco plants, infiltration of sulfated oligofucans at six spots in two leaves led to a strong time-dependent accumulation of SA in the treated zones while a significant accumulation of SA, but of smaller magnitude, was also recorded later outside of the infiltrated areas as well as in the upper, untreated leaf (Fig. 4). Infiltration with oligofucans induced a clear accumulation of PR-1 acidic proteins in the infiltrated zones from 2 to 8 days after treatment (Fig. 5A). Accumulation of acidic PR-1 proteins was also observed outside of the treated areas and in the upper, nontreated leaf 4 and 8 days after treatment, respectively (Fig. 5B, C). The level of PR-1 accumulation in the upper, untreated leaves of plants exposed to oligofucans was similar to that in plants expressing SAR after an inoculation with tobacco mosaic virus (TMV), but acidic PR-1 proteins accumulated earlier in these plants (Fig. 5C). Based on the trypan blue test (Klarzynski et al. 2000; Koch and Slusarenko 1990) with both isolated cells and leaves, fucan oligosaccharides induced no cell death in tobacco, including at the microscopic level (data not shown).

\section{Oligofucans locally and systemically induce SA-dependent resistance to TMV.}

To determine whether oligofucans can induce disease resistance in tobacco, mature leaves were infiltrated with various doses of oligosaccharides at six spots in two leaves, and five days later, they were inoculated with TMV in both the treated leaves and in the upper, untreated leaf. Stimulation of resistance was determined 6 days after TMV inoculation by measuring the number and size of TMV-induced lesions inside and outside the infiltrated areas of treated leaves as well as in the upper, untreated leaf. As shown in Figure 6, treatment with oligofucans induced a strong reduction of both the number of and the size of the lesions induced by TMV. Typically, the number of visible lesions was reduced by two- to threefold compared with the control plants (data not shown). Locally, i.e., in the areas infiltrated with oligofucans, lesion size was significantly reduced (Student test) for doses of oligosaccharides as low as $2 \mu \mathrm{g} \mathrm{ml}^{-1}$, the response saturating at $200 \mu \mathrm{g} \mathrm{ml}^{-1}$ (Table 1). Doses of $200 \mu \mathrm{g} \mathrm{ml}^{-1}$ oligofucans and above also markedly reduced lesion size outside the treated zones and in the upper, untreated leaf to a level comparable to that obtained after a primary virus inoculation known to induce SAR in tobacco (Table 1). In contrast, the size of the lesions in control plants was only slightly reduced in the areas infiltrated with water alone, while no reduction at all was observed in the other leaf areas or in the systemic leaves. In this test, laminarin at the concentration of $200 \mu \mathrm{g} \mathrm{ml}^{-1}$ proved less efficient than the fucan oligosaccharides in inducing resistance (Table 1).
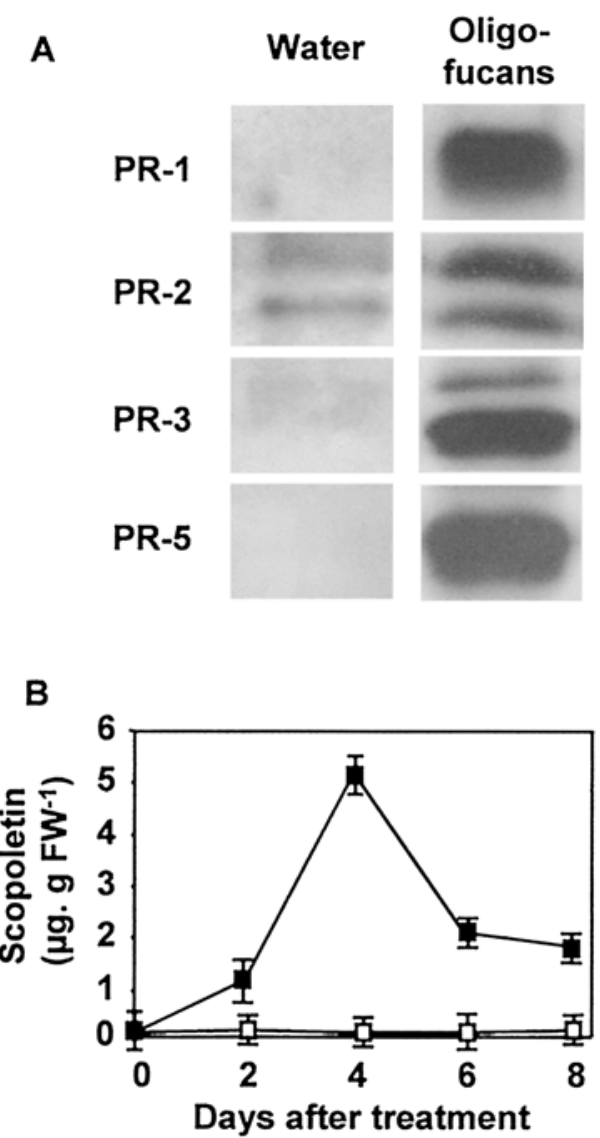

Fig. 3. Accumulation of antimicrobial compounds in tobacco leaves treated with fucan oligosaccharides. A, Accumulation of pathogenesis-related (PR) proteins determined by immunodetection $48 \mathrm{~h}$ after treatment. Leaves were infiltrated at discrete spots with water or with $200 \mu \mathrm{g}$ of oligofucans $\mathrm{ml}^{-1}$, were allowed to recover for 2 days, and then, the infiltrated areas were submitted to protein extraction. Extracts were assayed for total proteins and equivalent amounts (approximately $2 \mu \mathrm{g}$ of protein per lane) were fractionated by sodium dodecyl sulfate-polyacrylamide gel electrophoresis, were electrotransferred, and were immunodetected with antibodies raised against the PR protein families PR-1, PR-2, PR-3, and PR-5, respectively. B, Kinetics of total scopoletin accumulation in tobacco leaves. Tobacco leaves were infiltrated at discrete spots with 200 $\mu \mathrm{g}$ of oligofucans $\mathrm{ml}^{-1}$ (black square) or with water (open square), the treated tissues were harvested at intervals, and scopoletin was quantified by high-performance liquid chromatography. Data are representative of three independent experiments. 
In order to estimate the time required for the induction of resistance by oligofucans and the duration of induced resistance, tobacco leaves were infiltrated as described above and inoculated with TMV at intervals varying from $1 \mathrm{~h}$ to 15 days after the oligosaccharide treatment. Plants inoculated at $1 \mathrm{~h}$ or 2 days after the infiltration of oligosaccharides showed no increased resistance to TMV (Table 2), while those inoculated either at 5 (Table 1), 10, or 15 days (Table 2) exhibited a significant reduction in lesion size.

Similar experiments were performed with transgenic tobacco lines expressing bacterial salicylate hydroxylase (NahG plants), which do not accumulate SA and do not develop SAR upon primary infection with TMV (Gaffney et al. 1993; Delaney et al. 1994). Interestingly, NahG tobacco plants infiltrated with oligofucans and inoculated 5 days later with TMV did not show any significant reduction in lesion size compared with controls, including in the zones treated with the oligosaccharides (Table 3).

\section{DISCUSSION}

\section{Sulfated fucan oligosaccharides,}

a new class of defense response elicitors in tobacco.

The sulfated fucans of brown algae are known to consist of a backbone of $\alpha$-L-fucose, substituted by sulfate-ester groups, and masked with ramifications containing other monosaccharide residues (Kloareg and Quatrano 1988). The fucan from the fucoid alga Ascophyllum nodosum was recently described (Chevolot et al. 2001) as containing high proportions of fucan
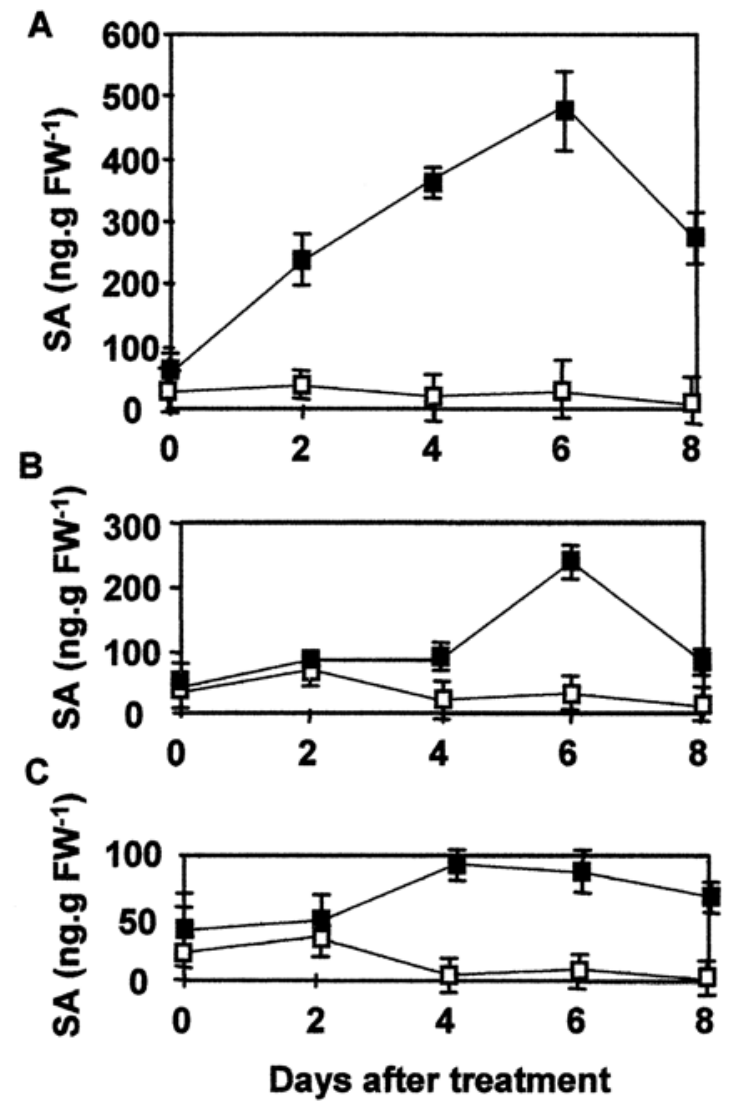

Fig. 4. Accumulation of salicylic acid in tobacco plants treated with fucan oligosaccharides. Leaves (two per plant) were infiltrated at six spots per leaf with $200 \mu \mathrm{g}$ of oligofucans $\mathrm{ml}^{-1}$ (black square) or water (open square). Salicylic acid was quantified by high-performance liquid chromatography analysis in $\mathbf{A}$, infiltrated tissues, $\mathbf{B}$, surrounding tissues , and $\mathbf{C}$, in the untreated upper leaf. Bars indicate standard errors from three independent experiments. fragments made of the approximately fivefold repetition of the disaccharide 1,3- $\alpha$-L-Fuc $p$-2( $\left(\mathrm{OSO}_{3}\right)-1,4-\alpha$-L-Fuc $p-2,3\left(\mathrm{diOSO}_{3}\right)$, referred to as $\mathrm{B}-\mathrm{A}$ and in which the $\mathrm{B}$ fucosyl residue can more or less regularly bear a substituent at C-4 (sulfate, xylose, fucose, or sulfated fucose). The same structure was recognized in the fucan of another fucoid alga, Fucus vesiculosus (Chevolot et al. 2001). Since the fucoidan of Pelvetia canaliculata consists of a highly sulfated homofucan with an average sulfate to fucose molar ratio of 1.5 (Kloareg et al. 1986), this fucan is also very likely to harbor such oligosaccharides. Consistently, $\alpha-$ L-Fuc $p$ - 2,3-( diOSO$\left._{3}\right)-1 \rightarrow 3 \alpha-\mathrm{L}-\mathrm{Fuc} p-2-\left(\mathrm{OSO}_{3}\right)-1 \rightarrow 4-\alpha-\mathrm{L}-\mathrm{Fuc} p$ $2,3-\left(\mathrm{diOSO}_{3}\right)-1 \rightarrow 3-\alpha$-L-Fuc $p-2-\left(\mathrm{OSO}_{3}\right)$ and $\alpha$-L-Fuc $p-2,3-$ $\left(\right.$ diOSO$\left._{3}\right)-1 \rightarrow 3-\alpha$-L-Fucp-2-(OSO$)_{3}-1 \rightarrow 4-\alpha$-L-Fucp-2,3-(diOSO$)_{3}-$ $1 \rightarrow 3-\alpha$-L-Fuc $p$-2-( $\left.\mathrm{OSO}_{3}\right)-1 \rightarrow 4-\alpha-\mathrm{L}-\mathrm{Fuc} p-2,3-\left(\mathrm{diOSO}_{3}\right)-1 \rightarrow 3-\alpha-$ L-Fucp-2-( $\left.\mathrm{OSO}_{3}\right)$ were conspicuous in the enzyme hydrolysis products of this fucan (V. Descamps, unpublished data).

Here, we show that these fucan oligosaccharide preparations elicit a variety of defense responses in tobacco. Treatment of cell suspension cultures with these molecules rapidly induced typical transient defense responses such as cytosolic acidification, shown by the alkalinization of the culture medium, and the production of activated oxygen species, as seen by the release of $\mathrm{H}_{2} \mathrm{O}_{2}$ (Fig. 1A and $\mathrm{B}$ ). Perception of fucan oligosaccharides by isolated tobacco cells was then followed by a strong induction of PAL and LOX activities several hours later (Fig. 2A and B). Furthermore, tobacco leaves infiltrated by the oligosaccharides strongly accumulated the defense signal SA (Fig. 4) and the phytoalexin scopoletin (Fig 3B), as well as

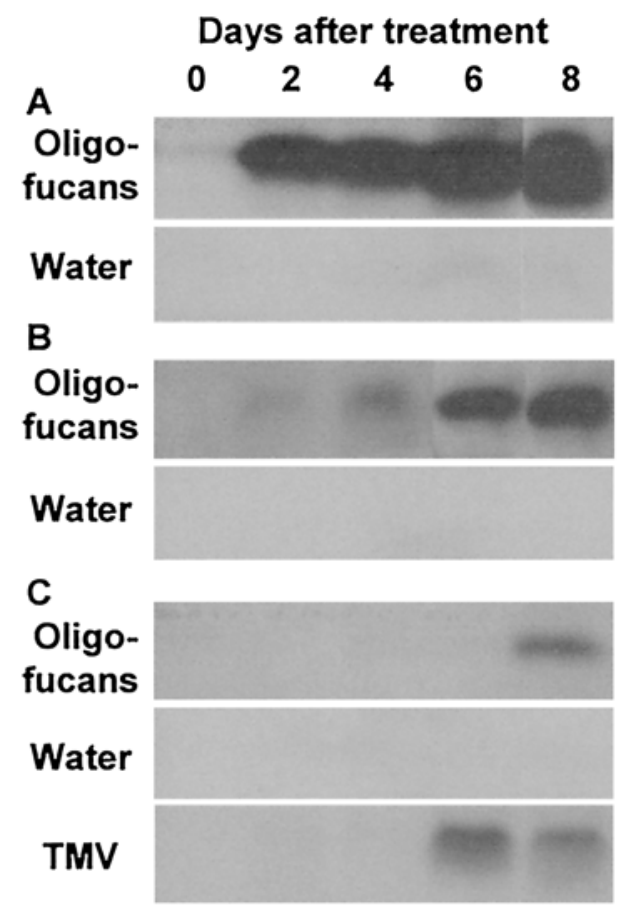

Fig. 5. Accumulation of acidic PR-1 proteins in tobacco plants treated with fucan oligosaccharides. Two leaves per plant were infiltrated at six spots with water or with $200 \mu \mathrm{g}$ of fucan oligosaccharides $\mathrm{ml}^{-1}$. Proteins were extracted from the $\mathbf{A}$, infiltrated tissues, $\mathbf{B}$, tissues surrounding the infiltrated zones, and $\mathbf{C}$, tissues of untreated upper leaf. For comparison, two leaves per plant were independently inoculated with $0.1 \mu \mathrm{g}$ of tobacco mosaic virus (TMV) $\mathrm{ml}^{-1}$, and proteins were extracted from the untreated upper leaf tissues. Extracts were assayed for total proteins, and equivalent amounts ( $2 \mu \mathrm{g}$ of protein per lane) were fractionated by sodium dodecyl sulfatepolyacrylamide gel electrophoresis, were electrotransferred to a nylon membrane, and were immunodetected with antibodies raised against acidic tobacco PR-1. Data are representative of three independent experiments. 
several typical PR proteins (Fig. 3A) including antimicrobial proteins PR-1 and thaumatin-like PR-5 and enzymes with $\beta$ 1,3 glucanase (PR-2) or chitinase (PR-3) activity.

The above results show that sulfated fucan oligosaccharides induce in tobacco the multiplicity of events thought to be directly involved in the defense cascade leading to resistance against microbial pathogens in plants, perception of the attack or attacker, early signaling processes, activation of secondary metabolic pathways, mobilization of signal molecules, and strong accumulation of antimicrobial molecules (Kombrink and Somssich 1995). Preincubation of tobacco cells with staurosporine abolished the medium alkalinization and oxidative responses to fucan oligosaccharides (Fig. 1), indicating that, as for other oligosaccharide elicitors, induction of the early responses is phosphorylation-dependent. Furthermore, based on our previous results with two other oligosaccharide defense elicitors of tobacco, laminarin and oligogalacturonides (Klarzynski et al. 2000), the responses induced by fucan oligosaccharides shared common features with those elicited by the former oligosaccharides, such as close similarities in the alkalinization and oxidative burst responses and in the kinetics of enzyme induction. Yet, refractory state analysis (Felix et al. 1998) clearly indicated that perception of sulfated oligofucans by tobacco cells does not involve the same sites as for that of laminarin or oligogalacturonides (Fig. 1C). In addition, fucan oligosaccharides induced significantly stronger defense responses. In particular, the maxima of induction of PAL and LOX activities by oligofucans (this study) were stronger compared with the oligoglucan laminarin and to oligogalacturonides (Klarzynski et al. 2000). Moreover, only the oligofucans triggered the accumulation of scopoletin, they induced a higher accumulation of PR proteins and were more efficient than laminarin in inducing resistance against TMV (Table 1). Taken together, these observations indicate that brown algal sulfated oligofucans are a novel class of oligosaccharide elicitors in tobacco.

Table 1. Oligofucans-mediated protection of Nicotiana tabacum cv. Xanthi nc against tobacco mosaic virus (TMV) ${ }^{\mathrm{a}}$

\begin{tabular}{|c|c|c|c|}
\hline Treatments & Tissues & $\begin{array}{l}\text { Mean lesion } \\
\text { diameter } \\
(\mathbf{m m})\end{array}$ & $\begin{array}{l}\text { Reduction in } \\
\text { lesion size }(\%)^{b}\end{array}$ \\
\hline Control & & $2.90 \pm 0.46$ & $\ldots$. (a) \\
\hline \multirow[t]{3}{*}{ Water } & Inf & $2.40 \pm 0.57$ & 17.4 (b) \\
\hline & Sur & $2.73 \pm 0.49$ & $5.9(\mathrm{a}, \mathrm{c})$ \\
\hline & Up & $2.72 \pm 0.55$ & $6.2(\mathrm{a}, \mathrm{c})$ \\
\hline \multirow[t]{3}{*}{ Oligofucans $\left(2 \mu \mathrm{g} \mathrm{ml}^{-1}\right)$} & Inf & $2.03 \pm 0.45$ & $30(\mathrm{~d})$ \\
\hline & Sur & $2.45 \pm 0.52$ & $15.7(\mathrm{~b}, \mathrm{c})$ \\
\hline & Up & $2.50 \pm 0.52$ & $14(b, c)$ \\
\hline \multirow[t]{3}{*}{ Oligofucans $\left(200 \mu \mathrm{g} \mathrm{ml}^{-1}\right)$} & Inf & $1.57 \pm 0.52$ & $45.7(\mathrm{e})$ \\
\hline & Sur & $1.65 \pm 0.56$ & $43.2(\mathrm{e})$ \\
\hline & Up & $1.66 \pm 0.49$ & $42.6(\mathrm{e})$ \\
\hline \multirow[t]{3}{*}{ Oligofucans $\left(1 \mathrm{mg} \mathrm{ml}^{-1}\right)$} & Inf & $1.52 \pm 0.59$ & $47.7(\mathrm{e})$ \\
\hline & Sur & $1.50 \pm 0.48$ & $48.4(\mathrm{e})$ \\
\hline & Up & $1.73 \pm 0.50$ & $40.4(\mathrm{~d}, \mathrm{e})$ \\
\hline \multirow{3}{*}{ Laminarin $\left(200 \mu \mathrm{g} \mathrm{ml}^{-1}\right)$} & Inf & $2.00 \pm 0.54$ & $31.2(\mathrm{~d})$ \\
\hline & Sur & $2.00 \pm 0.63$ & 31 (d) \\
\hline & Up & $2.10 \pm 0.55$ & $27.5(\mathrm{~d})$ \\
\hline TMV & Up & $1.67 \pm 0.45$ & $42.5(\mathrm{e})$ \\
\hline
\end{tabular}

${ }^{\mathrm{a}}$ Leaves (two per plant) were infiltrated at six spots with water, 2,200 or $1,000 \mu \mathrm{g} \mathrm{ml}^{-1}$ oligofucans, or $200 \mu \mathrm{g} \mathrm{ml}^{-1}$ laminarin or were inoculated with $0.1 \mu \mathrm{g} \mathrm{ml}^{-1}$ TMV. Later (5 days), treated and upper untreated leaves were inoculated with TMV. Untreated plants were inoculated with TMV for control. Lesion diameters were measured after 6 days in the infiltrated tissues (Inf), the tissues surrounding the infiltrated zones (Sur), and the tissues of the untreated upper leaf (Up). Mean and standard deviations were calculated from a minimum of 300 lesions.

${ }^{b}$ Values with the same letter are not statistically different at the risk of $5 \%$.
Sulfated fucan oligosaccharides are strong inducers of local and systemic resistance in tobacco.

In addition to eliciting a wide array of defense reactions, sulfated fucan oligosaccharides induced resistance against TMV in tobacco plants. As assayed by the reduction in both the number and size of viral lesions (Table 1), the level of acquired resistance was similar to that induced by a primary TMV inoculation, not only in the areas infiltrated with the oligosaccharides but also in the untreated tissues of these leaves as well as in the systemic leaves. Although we cannot rule out at this stage that fucan oligosaccharides did not move beyond the infiltrated tissues, we assume that such a movement in planta is very unlikely since it was shown that elicitors as diverse as elicitins (Baillieul et al. 1996; Dorey et al. 1997) and various oligosaccharides (Baydoun and Fry 1985; Kovalenko and Kluge 1988) remain localized within the areas of infiltration.

Interestingly also, the time course for the establishment, between 2 and 5 days after the oligosaccharide treatment, and the persistence, for at least 10 days (Table 2), of the acquired resistance was similar to the kinetics of the development of SAR following inoculation by TMV (Ross 1961). In addition, treatment with sulfated oligofucans induced both local and systemic accumulation of salicylic acid (Fig. 4) and acidic PR-1 proteins (Fig. 5), which are considered as two major markers of SAR in tobacco (Ryals et al. 1996; Sticher et al. 1997). Notably, the kinetics of the expression of acidic PR-1 proteins, at approximately 2 and 8 days after treatment (Fig. 5), as well as the level of the accumulation of SA (Fig. 4), up to 500 and $100 \mathrm{ng}$ per $\mathrm{g}$ of fresh weight in the treated tissues and the systemic leaf, respectively, were similar to those observed in tobacco plants primarily inoculated with TMV (Fig. 5C) (Malamy et al. 1990). Finally, no resistance against TMV was induced by fucan oligosaccharides in NahG transgenic tobacco lines (Table 3), indicating that, as in SAR resulting from primoinfection by TMV (Delaney et al. 1994; Dempsey and Klessig 1994), SA accumulation is required for the development of systemic resistance following the infiltration of elicitors.

Altogether, infiltration of tobacco leaves by fucan oligosaccharides resulted in the acquisition of a systemic resistance towards TMV, which, in its level, its kinetics, and in the behavior

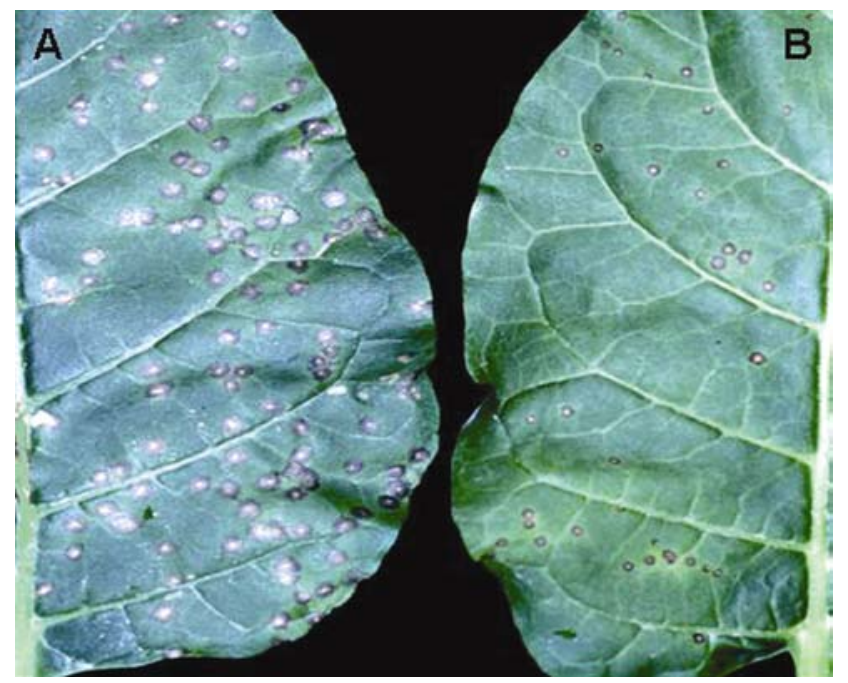

Fig. 6. Stimulation of systemic resistance against tobacco mosaic virus (TMV) infection in fucan oligosaccharides-treated plants. Leaves (two per plant) were infiltrated at six spots with $200 \mu \mathrm{g}$ of oligofucans $\mathrm{ml}^{-1}$ or water. After 5 days, treated leaves and the upper untreated leaf were inoculated with TMV. A, Representative photograph of the untreated upper leaf of water-treated plants. B, Representative photograph of the untreated upper leaf of oligofucans-treated plants. Photographs were taken 6 days after TMV inoculation. Data are representative of four replicates. 
of the biochemical markers investigated in this study, closely resembles the SAR induced by a primary inoculation of the virus. To our knowledge, this is the first comprehensive demonstration that oligosaccharide elicitors can induce SAR in tobacco. It is also worth noting here that, in contrast to elicitins (Ricci et al. 1989), treatment with fucan oligosaccharides did not cause cell death in tobacco suspension cultures nor in leaves, suggesting that HRs are not required for the induction of SAR in this plant.

\section{Biological significance \\ of the activity of sulfated fucan oligosaccharides.}

As discussed above, sulfated fucan oligosaccharides elicited a wide variety of defense reactions in tobacco plants and induced resistance against TMV, both locally and systemically. Based on the induction of PAL activity in cell suspensions, fucan oligosaccharides also elicited defense responses in parsley and wheat (data not shown). Since the enzyme digestion of the sulfated fucans of various brown algae yielded a consistent yet complex pattern of degradation products (V. Descamps, unpublished data), we have not undertaken a detailed description of structure-activity relationships in this new class of elicitors. However, based on the structural analyses of these polysaccharides (Chevolot et al. 2001) as well as on the analysis of the low-molecular weight digestion products (V. Descamps, unpublished data), repetitions of the disaccharide 1,3- $\alpha$-L-Fuc $p$ - $2\left(\mathrm{OSO}_{3}\right)-1,4-\alpha$-L-Fuc $p$ $2,3\left(\mathrm{diOSO}_{3}\right)$ likely were prevalent motifs in the fucan fragments used in this study. One may ask why such unique oligosaccharidic motifs from marine brown algae are recognized as potent defense signals by terrestrial plants. Short fucan branches are found in higher-plant hemicelluloses (Côté and Hahn 1994), and brown algal fucan oligosaccharides may, thus, be thought of as mimicking structural motifs of endogenous elicitors derived from hemicellulose. However, even though hemicellulose fragments are recognized as potent regulators of plant growth and morphogenesis (Côté and Hahn 1994), no evidence has been reported so far that these oligosaccharides elicit defense reactions.

Alternatively, brown algal fucan oligosaccharides may mimic exogenous elicitors of defense reactions in plants.

Table 2. Time of induction and duration of oligofucans-mediated protection of Nicotiana tabacum cv. Xanthi nc against tobacco mosaic virus (TMV) ${ }^{\mathrm{a}}$

\begin{tabular}{lccc}
\hline Treatments $^{\mathbf{b}}$ & Tissues & $\begin{array}{c}\text { Mean lesion } \\
\text { diameter }(\mathbf{m m})\end{array}$ & $\begin{array}{c}\text { Reduction in } \\
\text { lesion size (\%) }\end{array}$ \\
\hline Control & & $2.91 \pm 0.57$ & $\ldots .(\mathrm{a})$ \\
$1 \mathrm{~h}$ & Inf & $2.00 \pm 0.41$ & $31(\mathrm{~b})$ \\
& Sur & $2.77 \pm 0.51$ & $4.5(\mathrm{a})$ \\
& Up & $2.72 \pm 0.47$ & $6.2(\mathrm{a})$ \\
$48 \mathrm{~h}$ & Inf & $2.73 \pm 0.51$ & $5.9(\mathrm{a})$ \\
& Sur & $2.85 \pm 0.42$ & $1.7(\mathrm{a})$ \\
& Up & $2.82 \pm 0.40$ & $1.7(\mathrm{a})$ \\
10 days & Inf & $1.54 \pm 0.41$ & $46.9(\mathrm{~b})$ \\
& Sur & $1.58 \pm 0.38$ & $45.5(\mathrm{~b})$ \\
& Up & $1.62 \pm 0.43$ & $44.1(\mathrm{~b})$ \\
& Inf & $1.68 \pm 0.37$ & $42(\mathrm{~b})$ \\
& Sur & $1.62 \pm 0.36$ & $44.1(\mathrm{~b})$ \\
& Up & $1.65 \pm 0.36$ & $43.1(\mathrm{~b})$ \\
\hline
\end{tabular}

${ }^{a}$ Leaves (two per plant) were infiltrated at six spots with water or $200 \mu \mathrm{g}$ $\mathrm{ml}^{-1}$ oligofucans. After 1 or $48 \mathrm{~h}$ or 10 or 15 days, treated and upper untreated leaves were inoculated with TMV. Untreated plants were inoculated with TMV for control. Lesion diameters were measured after 6 days in the infiltrated tissues (Inf), the tissues surrounding the infiltrated zones (Sur), and the tissues of the untreated upper leaf (Up). Mean and standard deviations were calculated from a minimum of 300 lesions.

${ }^{\mathrm{b}}$ Pretreatment with oligofucans.

${ }^{c}$ Values with the same letter are not statistically different at the risk of $5 \%$.
Fucose is an essential structural element in various bacterial lipopolysaccharides (LPS), which are known to elicit defense responses in plants (Dow et al. 2000). Depending on its composition in rhamnose and fucose, a LPS from Pseudomonas fluorescens was indeed shown to induce systemic resistance in radish against Fusarium oxysporum f. sp. raphani (Leeman et al. 1995). Fucose is also a conserved element of several nodulation factors (Price 1999), and this monosaccharide is known to be involved in the activity of these elicitors in Rhizobiumlegume symbioses (Lamrabet et al. 1999).

In contrast to metazoans (Sugahara and Kitagawa 2000) and marine algae (Kloareg and Quatrano 1988), the extracellular matrix polysaccharides from land plants or bacteria (Sutherland 1994; Schäffer and Messner 2001) do not contain sulfate decorations. However, the ester-sulfate substituents of Nod factors are known to affect the host-range of rhizobia (Roche et al. 1991), and it was recently shown that the sulfated red algal galactans known as carrageenans are elicitoractive in tobacco and that their activity depends on their sulfate content (Mercier et al. 2001). Similarly, the activity of carrageenan oligosaccharides in enhancing the yields of microspore-derived embryos in Brassica oleracea var. italica was related to their sulfate content (Lemonnier-Le Penhuizic et al. 2001). Hence, ester-sulfate substituents appear to be a key feature in the activity of elicitors by terrestrial plants. The biological activity of fucan oligosaccharides in tobacco probably is also to be accounted for by the presence of such groups on their fucoidic backbone.

In conclusion, these results unambiguously show that homofucan oligosaccharides are potent elicitors in tobacco, leading to a wide array of defense reactions, including early responses such as the perturbation of proton fluxes and the production of activated oxygen species, as well as longer-term metabolic modifications, such as the accumulation of salicylic acid and antimicrobial compounds. Thus, fucan oligosaccharides can be thought of as a novel class of oligosaccharide elicitors in land plants, with a specific activity in tobacco even higher than that of $\beta-1,3$ glucans or oligogalacturonides. They also convey SAR to TMV, indicating that SAR can be induced by oligosaccharide elicitors even in the absence of cell death. Since the level and kinetics of the induced resistance were similar to those of the SAR obtained by TMV primoinfection, fucan oligosaccharides may be viewed as a novel biological elicitor for disease control in agronomic crops.

Table 3. Effects of oligofucans in transgenic NahG tobacco plants ${ }^{\mathrm{a}}$

\begin{tabular}{lccc}
\hline Treatments & Tissues & $\begin{array}{c}\text { Mean lesion } \\
\text { diameter }(\mathbf{m m})\end{array}$ & $\begin{array}{c}\text { Reduction in } \\
\text { lesion size }(\%)^{\mathbf{b}}\end{array}$ \\
\hline Control & & $3.92 \pm 0.65$ & $\ldots .(\mathrm{a})$ \\
Water & Inf & $3.86 \pm 0.62$ & $1.5(\mathrm{a})$ \\
& Sur & $3.95 \pm 0.63$ & $\ldots .(\mathrm{a})$ \\
Oligofucans $\left(200 \mu \mathrm{g} \mathrm{ml}^{-1}\right)$ & $\mathrm{Up}$ & $3.95 \pm 0.73$ & $\ldots .(\mathrm{a})$ \\
& Inf & $3.72 \pm 0.74$ & $5.1(\mathrm{a})$ \\
& Sur & $3.78 \pm 0.56$ & $3.5(\mathrm{a})$ \\
TMV & $\mathrm{Up}$ & $3.80 \pm 0.61$ & $3(\mathrm{a})$ \\
& $\mathrm{Up}$ & $3.65 \pm 0.54$ & 7 (a) \\
\hline
\end{tabular}

${ }^{a}$ Leaves (two per plant) were infiltrated at six spots with water, $200 \mu \mathrm{g}$ $\mathrm{ml}^{-1}$ oligofucans, or inoculated with $0.1 \mu \mathrm{g} \mathrm{ml^{-1 }}$ tobacco mosaic virus (TMV). After 5 days, treated and upper untreated leaves were inoculated with tobacco mosaic virus (TMV). Untreated plants were inoculated with TMV for control. Lesion diameters were measured after 6 days in the infiltrated tissues (Inf), the tissues surrounding the infiltrated zones (Sur), and the tissues of the untreated upper leaf (Up). Mean and standard deviations were calculated from a minimum of 300 lesions.

b Values with the same letter are not statistically different at the risk of 5\%. 


\section{MATERIALS AND METHODS}

\section{Plant material.}

Plants of Nicotiana tabacum cv. Xanthi nc, either wild type or transgenic NahG lines (Gaffney et al. 1993; Delaney et al. 1994), were grown from seeds in a greenhouse under controlled conditions and were used at the 8-leaf stage after 2 months in culture. Suspended cell cultures of Nicotiana tabacum cv. Bright Yellow were maintained in Murashige and Skoog medium at pH 5.8 (Duchefa, Haarlem, The Netherlands) supplemented with $0.2 \mathrm{~g} \mathrm{l}^{-1}$ of 2,4-D, $1 \mathrm{mg} \mathrm{l}^{-1}$ of thiamine, 100 $\mathrm{mg} \mathrm{l}^{-1}$ of myo-inositol, $200 \mathrm{mg} \mathrm{l}^{-1} \mathrm{KH}_{2} \mathrm{PO}_{4}$, and $30 \mathrm{~g} \mathrm{l}^{-1}$ of sucrose. Cells were grown in the dark on a rotary shaker (120 $\mathrm{rpm}, 25^{\circ} \mathrm{C}$ ) and subcultured weekly. Experiments with elicitors were performed at 6 days of subculture.

\section{Preparation of elicitors.}

Fucan was purified from the fucoid alga Pelvetia canaliculata as described previously (Mabeau and Kloareg 1987; Mabeau et al. 1990). It contained $32 \%$ fucose and $33 \%$ sulfate. The polysaccharide was hydrolyzed to completion $\left(25^{\circ} \mathrm{C}\right.$ for $\left.24 \mathrm{~h}\right)$ using an endo-fucanase preparation from a marine bacterium $(\mathrm{Cy}$ tophagales, family Flavobacteriaceae) referred to as SW5. Fucan oligosaccharides were recovered by ultrafiltration through a 500-Da cutoff membrane (Pall Filtron, St. Germain en Laye, France). Based on its monosaccharide composition as well as on its carbohydrate-PAGE, anion-exchange chromatography, and gel filtration profiles, this fraction consisted of highly acidic oligosaccharides with a mass below $10,000 \mathrm{Da}$ and containing high proportions of mono- or disulfated fucose residues bound by alternating $\alpha-1,3$ and $\alpha-1,4$ linkages (V. Descamps, unpublished data). Elicitor molarities were estimated by assuming that fucan oligosaccharides had an average polymerization degree of 10 fucose residues. Laminarin and oligogalacturonides were prepared as described previously (Klarzynski et al. 2000). Elicitors were dissolved in water before use.

\section{Assays of defense responses.}

Extracellular $\mathrm{pH}$ variations, hydrogen peroxide production, stimulation of PAL and LOX activities, and accumulation of PR proteins and of SA were assayed as described previously (Klarzynski et al. 2000). Scopoletin was quantified as follows. Tissue samples were extracted twice with $0.5 \mathrm{ml}$ of $90 \%$ (vol/vol) methanol and $0.4 \mathrm{ml}$ of absolute methanol. Supernatants were evaporated, were resuspended in $500 \mu \mathrm{l}$ water, were acidified with $166 \mu \mathrm{HCl} 12 \mathrm{~N}$, and were kept for $30 \mathrm{~min}$ at $80^{\circ} \mathrm{C}$. They were then submitted to two successive phase partitions with two volumes of ether. The ether extracts were dried under nitrogen and dissolved with an aqueous solution of $5 \%$ (vol/vol) acetonitrile for high-performance liquid chromatography (HPLC) analysis, then chromatographed on a C18 Nova Pak column (Waters Chromatography Div., Milford, MA, U.S.A.) equilibrated in $30 \mathrm{mM} \mathrm{NaH}_{2} \mathrm{PO}_{4}, \mathrm{pH} \mathrm{3}$, and $5 \%$ acetonitrile. A gradient of acetonitrile ( 0 to $35 \%$ in $20 \mathrm{~min}$ ) at a flow rate of $1 \mathrm{ml}$ per min was used for elution, and scopoletin was detected by fluorescence ( $\lambda$ ex 290 nm, $\lambda$ em 402 nm). For the assay of defense responses in tobacco leaves, one half of a fully developed leaf was infiltrated with $200 \mu$ of sulfated oligofucans solution, using a needleless syringe, whereas the other half was infiltrated with water as a control. Diphenyleneiodonium and staurosporine (stock solutions in dimethyl sulfoxide [DMSO]) (Sigma, St. Louis) were incubated at concentrations of $10 \mu \mathrm{M} 10 \mathrm{~min}$ before treatment of the tobacco suspended cell cultures with the oligosaccharidic elicitors. Controls were treated with diluted DMSO (final concentration at $0.01 \%$ ).

\section{Determination of the stimulation of resistance.}

Tobacco plants were infiltrated with various doses of fucan oligosaccharides or of water as a control at six spots (representing in total about half of the leaf surface) in two leaves per plant. At various times after the oligosaccharide treatment, leaf samples were harvested, and aliquots normalized by their fresh weight (approximately $200 \mathrm{mg}$ ) were taken from the infiltrated tissues, from the surrounding tissues, and from the first upper untreated leaves and were assayed for SA and acidic PR-1 protein accumulation, as previously described (Klarzynski et al. 2000). A parallel set of tobacco plants was used to evaluate the resistance against TMV as follows. Tobacco plants were first treated with oligofucans or with water as described above. At various intervals ( 1 and $48 \mathrm{~h}, 5,10$, and 15 days), the treated leaves and the first upper untreated leaf were then inoculated with TMV. For virus inoculation, the upper surfaces of leaves were rubbed with abrasive celite with a glass pad dipped into a solution of the common strain of TMV. The virus concentration (about $0.1 \mu \mathrm{g} \mathrm{ml}^{-1}$ ) was adjusted so as to induce about 300 local lesions per leaf of control, noninfiltrated plants. Acquisition of resistance was determined by measuring the size of TMVinduced lesions, using an ocular micrometer. In place of the elicitor treatment, TMV was separately inoculated to tobacco plants to induce a biological SAR. Each experiment was performed with four plants for each condition and was repeated three times. Statistical significance of the results was evaluated with the Student test at $P<0.05$.

\section{ACKNOWLEDGMENTS}

We are grateful to S. Kauffmann and R. Ménard (Institut de Biologie Moléculaire des Plantes, Strasbourg) for critically reading the manuscript.

\section{LITERATURE CITED}

Albersheim, P., and Darvill, A. 1985. Oligosaccharins. Sci. Am. 253:44-50. Baillieul, F., Fritig, B., and Kauffmann, S. 1996. Occurrence among Phytophthora species of a glycoprotein eliciting a hypersensitive response in tobacco and its relationships with elicitins. Mol. Plant-Microbe Interact. 9:214-216.

Baydoun, E. A. H., and Fry, S. C. 1985. The immobility of pectic substances in injured tomato leaves and its bearing on the identity of the wound hormone. Planta 165:269-276.

Benhamou, N., and Nicole, M. 1999. Cell biology of plant immunization against microbial infection: The potential of induced resistance in controlling plant diseases. Plant Physiol. Biochem. 10:703-719.

Boller, T. 1995. Chemoperception of microbial signals in plant cells. Annu. Rev. Plant Physiol. Plant Mol. Biol. 46:189-214.

Chevolot, L., Mulloy, B., Ratiskol, J., Foucault, A., and Colliec-Jouault, A. 2001. A disaccharide repeat unit is the major structure in fucoidans from two species of brown algae. Carbohydr. Res. 330:529-535.

Cohn, J., Sessa, G., and Martin, G. B. 2001. Innate immunity in plants. Curr. Opin. Immunol. 13:55-62.

Côté, F., and Hahn, M. G. 1994. Oligosaccharins: Structure and signal transduction. Plant Mol. Biol. 26:1379-1411.

Côté, F., Ham, K.-S., Hahn, M. G., and Bergmann, C. W. 1998. Oligosaccharide elicitors in host-pathogen interactions. Generation, perception, and signal transduction. Pages 385-432 in: Subcellular Biochemistry. B. B. Biswas and H. Das, eds. Plenum Press, New York.

Delaney, T. P., Uknes, S., Vernooij, B., Friedrich, L., Weymann, K., Negrotto, D., Gaffney, T., Gut-Rella, M., Kessmann, H., Ward, E., and Ryals, J. 1994. A central role of salicylic acid in plant disease resistance. Science 266:1247-1249.

Dempsey, D. A., and Klessig, D. F. 1994. Salicylic acid, active oxygen species and systemic acquired resistance in plants. Trends Cell. Biol. 4:334-338.

Dorey, S., Baillieul, F., Pierrel, M. A., Saindrenan, P., Fritig, B., and Kauffmann, S. 1997. Spatial and temporal induction of cell death, defense genes, and accumulation of salicylic acid in tobacco leaves reacting hypersensitively to a fungal glycoprotein elicitor. Mol. Plant Microbe Interact. 10:646-655.

Dow, M., Newman, M. A., and von Roepenack, E. 2000. The induction and modulation of plant defense responses by bacterial lipopolysac- 
charides. Annu. Rev. Phytopathol. 38:241-261.

Ebel, J. 1998. Oligoglucoside elicitor-mediated activation of plant defense. Bioessays 20:569-576.

Ebel, J., and Mithöfer, A. 1998. Early events in the elicitation of plant defence. Planta 206:335-348.

Felix, G., Baureithel, K., and Boller, T. 1998. Desensitization of the perception system for chitin fragments in tomato cells. Plant Physiol. 117:643-650.

Fritig, B., Heitz, T., and Legrand, M. 1998. Antimicrobial proteins in induced plant defense. Curr. Opin. Immunol. 10:16-22.

Gaffney, T., Friedrich, L., Vernooij, B., Negrotto, D., Nye, G., Uknes, S., Ward, E., Kessmann, H., and Ryals, J. 1993. Requirement of salicylic acid for the induction of systemic acquired resistance. Science 261:754-756

Grant, M., and Mansfield, J. 1999. Early events in host-pathogen interactions. Curr. Opin. Plant Biol. 2:312-319.

Klarzynski, O., Plesse, B., Joubert, J. M., Yvin, J. C., Kopp, M., Kloareg, B., and Fritig, B. 2000. Linear beta-1,3 glucans are elicitors of defense responses in tobacco. Plant Physiol. 124:1027-1038.

Kloareg, B., Demarty, M., and Mabeau, S. 1986. Polyanionic characteristics of purified homofucans from brown algae. Int. J. Biol. Macromol. 8:380-386.

Kloareg, B., and Quatrano, R. S. 1988. Structure of the cell walls of marine algae and ecophysiological functions of the matrix polysaccharides. Oceanogr. Mar. Biol. Annu. Rev. 26:259-315.

Kobayashi, A., Tai, A., Kanzaki, H., and Kawazu, K. 1993. Elicitor-active oligosaccharides from algal laminaran stimulate the production of antigungal compounds in alfalfa. Z. Naturforsch. 48c:575-579.

Koch, E., and Slusarenko, A. 1990. Arabidopsis is susceptible to infection by a downy mildew fungus. Plant Cell 2:437-445.

Kombrink, E., and Somssich, I. E. 1995. Defense responses of plants to pathogens. Adv. Bot. Res. 21:1-34

Kovalenko, A. G., and Kluge, S. 1988. Uptake, transport and persistance of ${ }^{14}$ C-yeast mannans in plants. Biochem. Physiol. Pflanzen. 183:283-290.

Lamrabet, Y., Bellogin, R. A., Cubo, T., Espuny, R., Gil, A., Krishnan, H B., Megias, M., Ollero, F. J., Pueppke, S. G., Ruiz-Sainz, J. E., Spaink, H. P., Tejero-Mateo, P., Thomas-Oates, J., and Vinardell, J. M. 1999. Mutation in GDP-fucose synthesis genes of Sinorhizobium fredii alters Nod factors and significantly decreases competitiveness to nodulate soybeans. Mol. Plant Microbe Interact. 12:207-217.

Leeman, M., Van Pelt, J. A., Den Ouden, F. M., Heinsbroek, M., Bakker, P. A. H. M., and Schippers, B. 1995. Induction of systemic resistance against fusarium wilt of radish by lipopolysaccharides of Pseudomonas fluorescens. Phytopathol. 85:1021-1027.

Lemonnier-Le Penhuizic, C., Chatelet, C., Kloareg, B., and Potin, P. 2001. Carrageenan oligosaccharides enhance stress-induced microspore embryogenesis in Brassica oleracea var. italica. Plant Sci. 160:1211-1220.

Lyon, G. D., Forrest, R. S., and Newton, A. C. 1996. SAR-The potential to immunise plants against infection. Pages 939-946 in: Brighton Crop Protection Conference. D. D. Slawson, ed. British Crop Protection Council, Brighton, U.K.

Mabeau, S., and Kloareg, B. 1987. Isolation and analysis of the cell walls of brown algae: Fucus spiralis, F. ceranoides, F. vesiculosus, F. serratus, Bifurcata bifurcate, and Laminaria digitata. J. Exp. Botany 38:15731580
Mabeau, S., Kloareg, B., and Joseleau, J. 1990. Fractionation and analysis of fucans from brown algae. Phytochemistry 29:2419-2442.

Malamy, J., Carr, J., Klessig, D., and Raskin, I. 1990. Salicylic acid: A likely endogenous signal in the resistance response of tobacco to viral infection. Science 250:1002-1004.

Mercier, L., Lafitte, C., Borderies, G., Briand, X., Esquerré-Tugayé, M. T., and Fournier, J. 2001. The algal polysaccharide carrageenans can act as an elicitor of plant defence. New Phythol. 149:43-51.

Nürnberger, T. 1999. Signal perception in plant pathogen defense. Cell Mol. Life Sci. 55:167-182.

Nürnberger, T., and Scheel, D. 2001. Signal transmission in the plant immune response. Trends Plant Sci. 6:372-379.

O’Donnell, V., Tew, D. G., Jones, O. T. G., and England, P. J. 1993. Studies on the inhibitory mechanism of iodonium compounds with special reference to neutrophil NADPH oxidase. Biochem. J. 290:41-49.

Patier, P., Yvin, J. C., Kloareg, B., Lienart, Y., and Rochas, C. 1993. Seaweed liquid fertilizer from Ascophyllum nodosum contains elicitors of plant D-glucanases. J. Appl. Phycol. 5:343-349.

Patier, P., Potin, P., Rochas, C., Kloareg, B., Yvin, J.C., and Liénart, Y 1995. Free or silica-bound oligokappa-carrageenans elicit laminarinase activity in Rubus cells and protoplasts. Plant Sci. 110:27-35.

Price, N. P. J. 1999. Carbohydrate determinants of Rhizobium-legume symbioses. Carbohydr. Res. 317:1-9.

Reglinski, T., Lyon, G. D., and Newton, A. C. 1994. Induction of resistance mechanisms in barley by yeast-derived elicitors. Ann. Appl. Biol. 124:509-517.

Ricci, P., Bonnet, P., Huet, J. C., Sallantin, M., Bauvais-Cante, F., Bruneteau, M., Billard, V., Michel, G., and Pernollet, J. C. 1989. Structure and activity of proteins from pathogenic fungi Phytophthora eliciting necrosis and acquired resistance in tobacco. Eur. J. Biochem. 183:555-563.

Roche, P., Debellé, F., Maillet, F., Lerouge, P., Faucher, C., Truchet, G., Dénarié, J., and Promé, J. C. 1991. Molecular basis of symbiotic host specificity in Rhizobium meliloti: nodH and nodPQ genes encode the sulfation of lipo-oligosaccharide signals. Cell 67:11311143.

Ross, A. F. 1961. Systemic acquired resistance induced by localized virus infections in plants. Virology 14:340-358.

Ryals, J. A., Neuenschwander, U. H., Willits, M. G., Molina, A., Steiner, H. Y., and Hunt, M. D. 1996. Systemic acquired resistance. Plant Cell 8:1809-1819.

Schäffer, C., and Messner, P. 2001. Glycobiology of surface layer proteins. Biochimie 83:591-599.

Somssich, I. E., and Hahlbrock, K. 1998. Pathogen defence in plants-a Paradigm of biological complexity. Trends Plant Sci. 3:86-90.

Sticher, L., Mauch-Mani, B., and Métraux, J. P. 1997. Systemic acquired resistance. Annu. Rev. Phytopathol. 35:235-270.

Sugahara, K., and Kitagawa, H. 2000. Recent advances in the study of the biosynthesis and functions of sulfated glycosaminoglycans. Curr. Opin. Struct. Biol. 10:518-527.

Sutherland, I. W. 1994. Structure-function relationships in microbial exopolysaccharides. Biotechnol. Adv. 12:393-449.

Ward, E., Uknes, S., Williams, S., Dincher, S., Wiederhold, D., Alexander D., Ahl-Goy, P., Metraux, J. P., and Ryals, J. 1991. Coordinate gene activity in response to agents that induce systemic acquired resistance. Plant Cell 3:1085-1094. 